\title{
Risk Factors for Pulmonary Embolism in Patients with Lung Cancer and Effects of Pulmonary Embolism on Prognosis
}

\section{Akciğer Kanserli Hastalarda Pulmoner Emboli için Risk Faktörleri ve Pulmoner Embolinin Prognoza Etkileri}

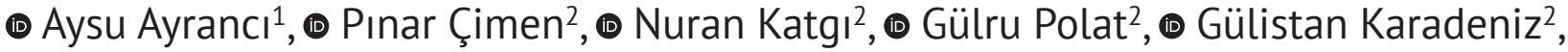 \\ ๑ Sami Deniz², $\bullet$ Dursun Tatar ${ }^{2}$ \\ ${ }^{1}$ Bakırçay University Çiğli Training and Research Hospital, Clinic of Pulmonology, Izmir, Turkey \\ ${ }^{2}$ University of Health Sciences Turkey, Dr. Suat Seren Chest Diseases and Surgery Training and Research Hospital, Clinic of Pulmonology, Izmir, Turkey
}

Background: Malignancy is an important risk factor for venous thromboembolism. Lung cancer is one of the frequently determined cancer associated with pulmonary embolism (PE). In our research, we compared lung cancer patients diagnosed with PE at the same period and lung cancer patients without PE. Besides, we investigated the risk factors that could predict PE in lung cancer patients, whether survival was different between patients who were diagnosed with PE incidentally and those who were diagnosed proactively.

Materials and Methods: The study's data came from lung cancer patients who were followed up between January 2012 and May 2017. A total of 235 patients with a thoracic angiographic computed tomography scan and/or ventilation/perfusion scintigraphy were included in the study. 109 patients with PE and 126 patients without a PE diagnosis were reported. Demographic information, lung cancer types and stages, time between lung cancer and PE, and survival were all recorded.

Results: The PE group's median age was 61 years (45-82 years), while the non-PE group's median age was 61 years (35-83 years). Adenocarcinoma was the most common histological form in the PE population, with higher leukocyte and C-reactive protein (CRP) levels and lower hemoglobin levels. The PE group had a mean survival time of 20.1 \pm 1.6 months, while the non-PE group had a mean survival time of $36.5 \pm 2.9$ months. The mean survival time was significantly longer in the non-PE group $(p<0.001)$.

Conclusion: Lung cancer patients with PE had a shorter survival. PE should be considered in patients with adenocarcinoma histology, leukocytosis, elevated CRP, anemia, and nutritional disorders.

Keywords: Lung cancer, prognosis, risk factors, pulmonary thromboembolism

Amaç: Malignite, venöz tromboembolizm için önemli risk faktörlerinden biridir. Akciğer kanseri, pulmoner emboli (PE) ile en sık ilişkili malignitelerden biridir. Çalışmamızda aynı dönemde PE tanısı almış akciğer kanseri hastaları ile PE'si olmayan akciğer kanseri hastalarını karşılaşıırdık ve PE’nin sağkalım üzerindeki etkisini göstermeyi amaçladık. Ayrıca akciğer kanseri hastalarında PE'yi öngörebilecek risk faktörlerini ve tesadüfen PE tanısı alan hastalarda ve diğerlerinde sağkalımda bir fark olup olmadığını araştırdık. Gereç ve Yöntemler: Çalışmadaki veriler Ocak 2012-Mayıs 2017 tarihleri arasında hastanemizde izlenen akciğer kanseri hastalarından elde edildi. Toraks anjiyo bilgisayarlı tomografi taraması ve/veya ventilasyon/perfüzyon sintigrafisi olan 235 hasta dahil edildi. Toraks anjiyo bilgisayarlı tomografi taraması ve ventilasyon/perfüzyon sintigrafisi ile yapılan incelemelerde PE tanısı alan 109, PE tanısı olmayan 126 hasta belirlendi. Demografik veriler, akciğer kanserinin tipleri ve evreleri, akciğer kanseri ile PE arasındaki süre ve sağkalım kaydedildi.

Bulgular: PE grubunun ortanca yașı 61 (45-82) yıl ve PE olmayan grubun ortanca yașı 61 yıl idi (35-83). PE grubunda en sık görülen histolojik tipin adenokarsinom olduğu, lökosit ve C-reaktif protein (CRP) değerlerinin daha yüksek, hemoglobin değerlerinin daha düşük olduğu görüldü. Akciğer kanseri tanısı konulduktan sonraki ortalama sağkalım süreleri karşılaştırıldığında; PE grubunun ortalama sağkalım süresi $20,1 \pm 1,6$ ay ve $P E$ olmayan grubun ortalama sağkalım süresi $36,5 \pm 2,9$ aydı. Ortalama sağkalım süresi $P E$ olmayan grupta anlamlı olarak daha uzundu $(p<0,001)$.

Address for Correspondence: Aysu Ayrancı, Bakırçay University Çiğli Training and Research Hospital, Clinic of Pulmonology, İzmir, Turkey E-mail: draysu87@gmail.com ORCID ID: orcid.org/0000-0002-8939-336X

Received: 03.02.2021 Accepted: 01.07.2021 
Sonuç: Son olarak, PE’li akciğer kanseri hastalarının daha kısa hayatta kaldıklarını bulduk. Adenokarsinom histolojisi, lökositoz, yüksek CRP, anemi ve beslenme bozuklukları olan hastalarda, nefes darlığı ve göğüs ağrısı akciğer kanserine atfedilmeden önce PE de düşünülmelidir.

Anahtar Kelimeler: Akciğer kanseri, prognoz, risk faktörü, pulmoner tromboembolizm

\section{Introduction}

One of the most important risk factors for venous thromboembolism (VTE) is cancer, which raises the risk of VTE by 2-4 times. VTE composes of pulmonary embolism (PE) and deep vein thrombosis (DVT), and cancer patients are believed to have higher rate of VTE than the patients without cancer (1). The development of VTE in cancer patients is influenced by many factors. Thrombosis vulnerability is increased by elevated D-dimer, C-reactive protein (CRP), thrombosis history, and obesity $(2,3)$. VTE is associated with a poor prognosis in cancer patients according to recent reports, and VTE is the second cause of death after all types of cancer $(4,5,6)$. Lung cancer is one of the most frequently determined cancer associated with PE, and the risk of VTE is 20 times higher in lung cancer patients (7). PE is linked to an increase in patients' mortality rates. It has been shown in many clinical studies that PE is responsible for approximately $10 \%$ of deaths in lung cancer $(8,9,10,11,12)$.

Respiratory symptoms are often associated with the underlying malignancy or disease progression in lung cancer patients. This may cause delay in the diagnosis of PE (13). Also, the widespread use of multi-detector computed tomography $(\mathrm{CT})$ in the routine staging and follow-up period has caused an increase in the incidence of incidental PE (14). Although incidental PE cases have displayed different characteristics in comparative studies with symptomatic PE cases, similar approaches have been recommended according to the guidelines $(15,16)$.

Therefore, early detection of PE is important, and starting early anticoagulation reduces the mortality rate up to 4 times (13). We compared lung cancer patients diagnosed with PE with lung cancer patients without PE during the same time span in order to demonstrate the impact of PE on survival. In addition, we assessed the risk factors that could predict PE in lung cancer patients, because survival was different between patients who were diagnosed with PE incidentally and those who were diagnosed proactively.

\section{Material and Methods}

\section{Study Design}

The data in this study were obtained from lung cancer patients who were followed up in a tertiary reference hospital for chest diseases between January 2012 and May 2017. The study was designed retrospectively and approval was obtained from the Local Ethics Committee of the our hospital (no: 49109414-806.02.02). Lung cancer patients diagnosed and/or followed up in our hospital over a 5-year period were analyzed using data obtained from the hospital information system. The medical histories of lung cancer patients were reviewed retrospectively. In this study, patients with thoracic angiographic $\mathrm{CT}$ and ventilation/perfusion (V/O) scintigraphy were included in the study. The eighth tumor-node-metastasis (TNM) classification (17) was used to stage the patients with lung cancer, who were included in the study. PE was diagnosed with a CT scan as a strongly delineated pulmonary arterial filling defect present in at least two consecutive image parts and situated centrally inside the vessel or with extreme angles at the walls' interface (18). A diagnosis of PE was also made based on the results of a ventilation/perfusion (V/O) scan that met the high likelihood criterion (19).

\section{Clinical Data}

The data of the patients were examined retrospectively and age, gender, body mass index, smoking status, additional diseases, lung cancer type, date of diagnosis, stage, treatments, date of PE detection, lung cancer stage at the time of PE detection, complaints, additional risk factors, DVT status, laboratory parameters, time between lung cancer and $P E$, and survival were recorded. The group in which PE was detected by thorax angiographic $\mathrm{CT}$ and V/Q scintigraphy was defined as the PE group. The group without PE was defined as the non-PE group. The patients in these two groups were matched for age, gender, histological type and stage. In addition, the patients in the PE group were divided into two as those with active complaints and those detected incidentally. The non-incidental group was investigated for the suspicion of PE and detected to have PE, and the incidental group included the cases in which $\mathrm{PE}$ was detected in the thoracic angiographic CT and/or V/Q scintigraphy performed for any reason during the followup. Their survival was recorded. Survival was evaluated as overall survival which was from the diagnosis. 


\section{Statistical Analysis}

SPSS 18 was used to analyze the results (Statistical Package for the Social Sciences, Chicago, Illinois). Normal distributions with continuous variables and subgroups were used for both the sample size and the normal distribution analyses. The Kaplan-Meier method was used to measure intergroup survival, and the Mann-Whitney $U$ test (nonparametric) was employed to compare these variables. In the multivariable analysis, variables with $p<0.05$ in the univariable analysis were included. To find independent risk factors for $\mathrm{PE}$, researchers used multivariable stepwise logistic regression analysis. The hazard ratio and confidence interval for the 95 percent were determined. The type 1 error coefficient was set at alpha $=0.05$ for all statistical methods. In cases where the $p$ value was less than 0.05 , the difference between the groups was evaluated as statistically significant.

\section{Results}

The clinical data of 235 lung cancer patients were analyzed. One hundred-nine patients were classified as having PE. One hundred 26 patients without a diagnosis of PE were determined with CT and scintigraphy. Table 1 lists the characteristics of the patients. Two groups of patients were formed as the PE group and non-PE group. The PE group included 109 patients (male/female: 91/18) and the non-PE group included 126 (male/female: 108/18) patients. The PE group's median age was 61 years (45-82 years), while the non-PE group's median age was 61 years (3583 years). A comorbid disorder was observed in $61.5 \%$ of patients in the PE group and $57.1 \%$ of patients in the non-PE group. The most common comorbidity in the PE group was hypertension (25.7\%), while the most common comorbidity in the non-PE group was chronic obstructive pulmonary disease (COPD) (23\%) (Table 1). White blood cell (WBC), pH and CRP were significantly higher, while hemoglobin $(\mathrm{Hb})$, pressure of partial oxygen $\left(\mathrm{pO}_{2}\right)$, pressure of partial carbon dioxide $\left(\mathrm{pCO}_{2}\right)$, albumin and protein were significantly lower in the PE group when the cases were hospitalized. In the PE group, adenocarcinoma (56.9\%) was the most prevalent histological type, whereas squamous cell carcinoma (46\%) was the most common histological type in the non-PE group. The majority of lung cancer cases in both the PE group and non-PE group were in stage 3 and 4 . The rate of patients who received chemotherapy was higher in the nonPE group compared to the other group $(p<0.05)$.

When the time between a patient's diagnosis of lung cancer and the onset of $\mathrm{PE}$ is divided into months, the number of those who developed PE in 0-6 months after diagnosis was 40 (36.6\%), the number of those who developed PE in

\begin{tabular}{|c|c|c|c|}
\hline & $\begin{array}{l}\text { PE group } \\
(n=109)\end{array}$ & $\begin{array}{l}\text { Non-PE } \\
\text { group } \\
(n=126)\end{array}$ & $\mathbf{p}$ \\
\hline Age & $61(45,82)$ & $61(35,83)$ & 0.572 \\
\hline Gender (male/female) & $91 / 18$ & $108 / 18$ & 0.771 \\
\hline Smoking history (+/-) & 98/11 & $106 / 20$ & 0.417 \\
\hline BMI & $25.9 \pm 3.5$ & $26 \pm 5.1$ & 0.962 \\
\hline \multicolumn{4}{|l|}{ Comorbidities } \\
\hline DM & $13(12 \%)$ & $13(10.3 \%)$ & 0.854 \\
\hline Hypertension & $28(25.7 \%)$ & $20(15.9 \%)$ & 0.089 \\
\hline Cardiovascular disease & $14(12.8 \%)$ & $16(12.7 \%)$ & 0.973 \\
\hline COPD & $24(22 \%)$ & $29(23 \%)$ & 0.979 \\
\hline Other & $3(2.8 \%)$ & $10(8 \%)$ & 0.058 \\
\hline \multicolumn{4}{|l|}{ Histologic types } \\
\hline Squamous cell carcinoma & 30 (27.5\%) & $58(46 \%)$ & \multirow{5}{*}{0.052} \\
\hline Adenocarcinoma & $62(56.9 \%)$ & 45 (35.7\%) & \\
\hline Small cell carcinoma & $16(13.7 \%)$ & 20 (15.9\%) & \\
\hline Mesothelioma & $1(0.9 \%)$ & $2(1.6 \%)$ & \\
\hline Large cell carcinoma & 0 & $1(0.8 \%)$ & \\
\hline \multicolumn{4}{|l|}{ Stage } \\
\hline 1 & $12(11 \%)$ & 15 (11.9\%) & \multirow{4}{*}{0.433} \\
\hline II & 14 (12.8\%) & 26 (20.6\%) & \\
\hline III & 45 (41.3\%) & 46 (36.5\%) & \\
\hline IV & $38(34.9 \%)$ & 39 (30.2\%) & \\
\hline Chemotherapy treatment & 86 (78.9\%) & 116 (92.1\%) & 0.007 \\
\hline Radiotherapy treatment & $62(56.9 \%)$ & 77 (61.1\%) & 0.511 \\
\hline Operation & $25(22.9 \%)$ & $21(16.7 \%)$ & 0.297 \\
\hline \multicolumn{4}{|l|}{ Laboratory data } \\
\hline WBC $\left(x 10^{9} / L\right)$ & $11.2 \pm 4.4$ & $9.4 \pm 3.9$ & 0.0001 \\
\hline Hemoglobin (mg/dL) & $11.8 \pm 1.5$ & $13.1 \pm 1.7$ & 0.0001 \\
\hline Platelet (x109/L) & $291 \pm 145$ & $303 \pm 112$ & 0.136 \\
\hline $\mathrm{PO}_{2}(\mathrm{mmHg})$ & $69.4 \pm 16.6$ & $87.4 \pm 18.9$ & 0.0001 \\
\hline $\mathrm{PCO}_{2}(\mathrm{mmHg})$ & $31,9 \pm 6$ & $39.1 \pm 7.9$ & 0.0001 \\
\hline $\mathrm{pH}$ & $7.47 \pm 0.05$ & $7.41 \pm 0.04$ & 0.0001 \\
\hline Protein (g/dL) & $6.6 \pm 0.7$ & $7 \pm 0.6$ & 0.0001 \\
\hline Albumin (g/dL) & $3.4 \pm 0.5$ & $3.8 \pm 0.5$ & 0.0001 \\
\hline $\mathrm{CRP}(\mathrm{mg} / \mathrm{dL})$ & $7.3 \pm 6.6$ & $5.2 \pm 5.5$ & 0.005 \\
\hline \multicolumn{4}{|c|}{$\begin{array}{l}\text { PE: Pulmonary embolism, BMI: Body mass index, DM: Diabetes } \\
\text { mellitus, COPD: Chronic obstructive pulmonary disease, WBC: White } \\
\text { blood cell, } \mathrm{pO}_{2} \text { : Partial pressure of oxygen, } \mathrm{pCO}_{2} \text { : Partial pressure of } \\
\text { carbon dioxide, CRP: C-reactive protein }\end{array}$} \\
\hline
\end{tabular}

6-12 months was 25 (22.9\%), and the number of those who developed PE after 12 months was 24 (22\%). In the other 20 (18.3\%) patients, PE and lung cancer were diagnosed at 
the same time. In other words, 60 (54.9\%) of the cases were diagnosed with PE in the first 6 months (Figure 1). When these periods-were evaluated together, the average time from the first-diagnosis of lung cancer to the development of pulmonary thromboembolism was calculated as $8.1 \pm 5.8$ months.

In the PE group, 80 patients applied to the hospital with symptoms and the most common symptoms were dyspnea (68\%) and chest pain (27.5\%). Twenty-nine (26.6\%) patients were diagnosed with PE incidentally during follow-up period for lung cancer. When the lower extremity venous Doppler ultrasonography reports of the PE group were examined, DVT was detected in 38 (34.9\%) of the patients.

When comparing the PE group with the non-PE group, leukocyte count and CRP levels were significantly higher, while protein, albumin, $\mathrm{Hb}$, and hematocrit levels were significantly lower. Furthermore, the PE group's $\mathrm{pO}_{2}$ and $\mathrm{pCO}_{2}$ levels were found to be substantially lower than in the other group $(p<0.05)$ (Table 1$)$.

In the multivariable analysis performed for the occurrence of PE in lung cancer; albumin cut-off $\leqslant 3.5$, hemoglobin cut-off $\leqslant 13.6$ and protein cut-off $\leqslant 7.1$, WBC cutoff $>10$ and CRP cut-off $>4$ were found to increase the risk of PE (Figure 2). It has been found that hypoalbuminemia,

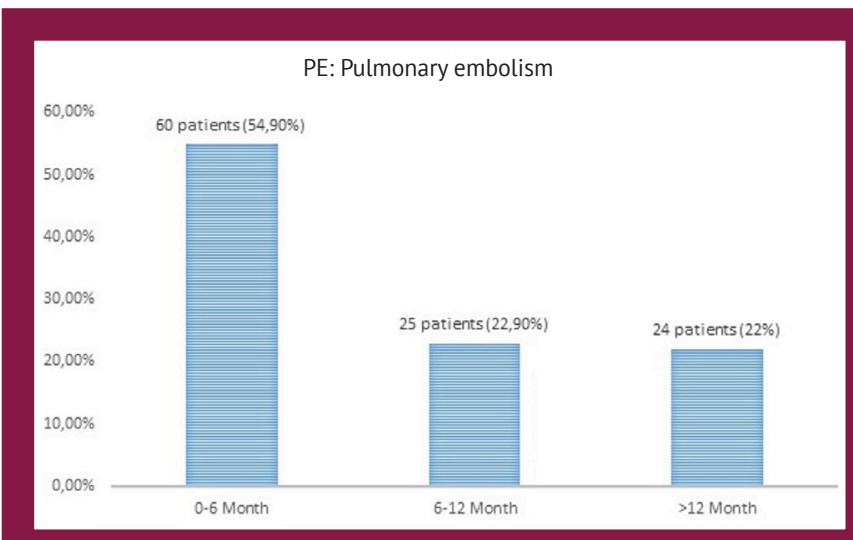

Figure 1. Time to PE diagnosis hypoproteinemia, anemia, leukocytosis and increased CRP level significantly increase the risk of developing PE in lung cancer [odds ratio (OR) value of 2.33, 2.79, 5.14, 2.86 and 2.84, respectively] (Table 2).

When comparing the mean survival period after a lung cancer diagnosis, the PE group had a mean survival period of 20.1 \pm 1.6 (16.8-23.4) months, while the non-PE group had a mean survival period of $36.5 \pm 2.9$ (30.6-42.3) months. The non-PE group had a slightly longer average survival period $(p<0.001)$ (Figure 3).

The mean survival period of coincidentally detected cases was $11.8 \pm 9.9$ months, while the mean survival period of cases with active complaints was calculated as $7.2 \pm 8.3$ months, when compared to other PE patients who were randomly determined $(p<0.05)$ (Figure 4).

\section{Discussion}

Patients with PE were found to have a slightly shorter life expectancy rate than those without PE. Adenocarcinoma was found to be the most common histological type in the

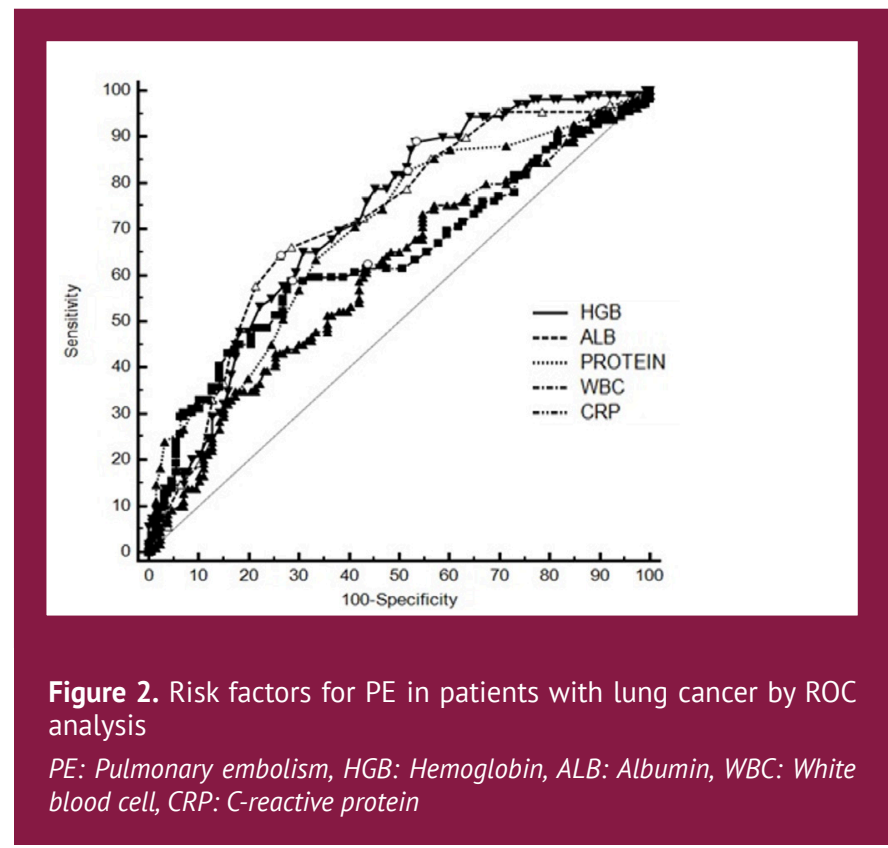

Table 2. Risk factors for PE in patients with lung cancer by roc analysis

\begin{tabular}{|l|l|l|l|l|l|l|}
\hline Factor & Cut-off & Sensitivity & Specifity & OR & AUC & p \\
\hline Albumin $(\mathrm{g} / \mathrm{dL})$ & $\leqslant 3.5$ & $64.2 \%$ & $56.3 \%$ & 2.33 & $0.71(0.65-0.77)$ & $<0.0001$ \\
\hline $\mathrm{Hb}(\mathrm{mg} / \mathrm{dL})$ & $\leqslant 13.6$ & $88.9 \%$ & $46.8 \%$ & 5.14 & $0.72(0.66-0.78)$ & $<0.0001$ \\
\hline Protein $(\mathrm{g} / \mathrm{dL})$ & $\leqslant 7.1$ & $82.5 \%$ & $48.4 \%$ & 2.79 & $0.69(0.62-0.75)$ & $<0.0001$ \\
\hline WBC $(\mathrm{mg} / \mathrm{dL})$ & $>10$ & $58.7 \%$ & $71.4 \%$ & 2.86 & $0.63(0.57-0.69)$ & 0.0002 \\
\hline CRP $(\mathrm{mg} / \mathrm{dL})$ & $>4$ & $62.3 \%$ & $56.3 \%$ & 2.84 & $0.60(0.54-0.66)$ & 0.0045 \\
\hline PE: Pulmonary embolism, OR: Odds ratio,AUC: Area under the curve, Hb: Hemoglobin, WBC: White blood cell, CRP: C-reactive protein & \\
\hline
\end{tabular}




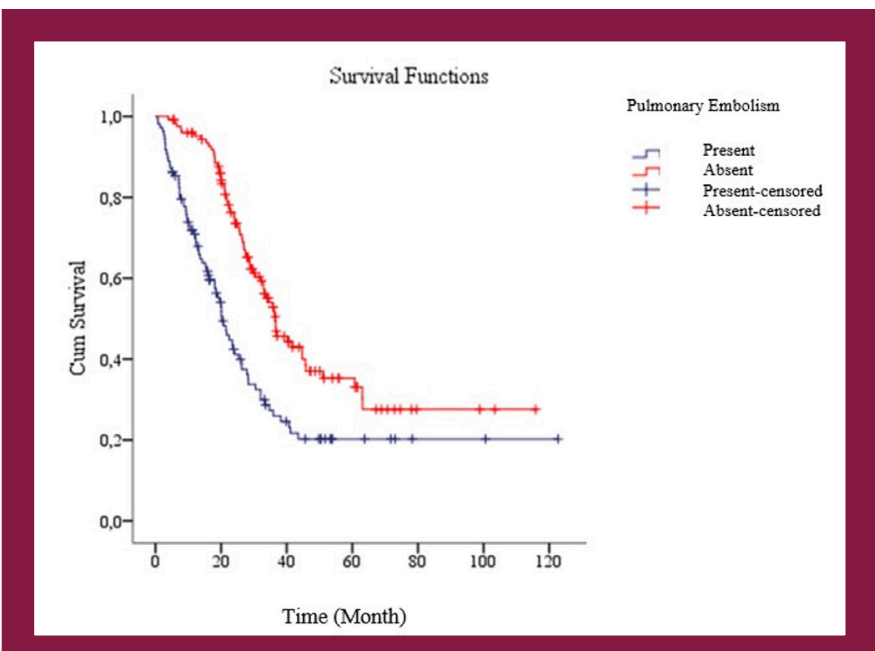

Figure 3. Comparison of life cycle between groups

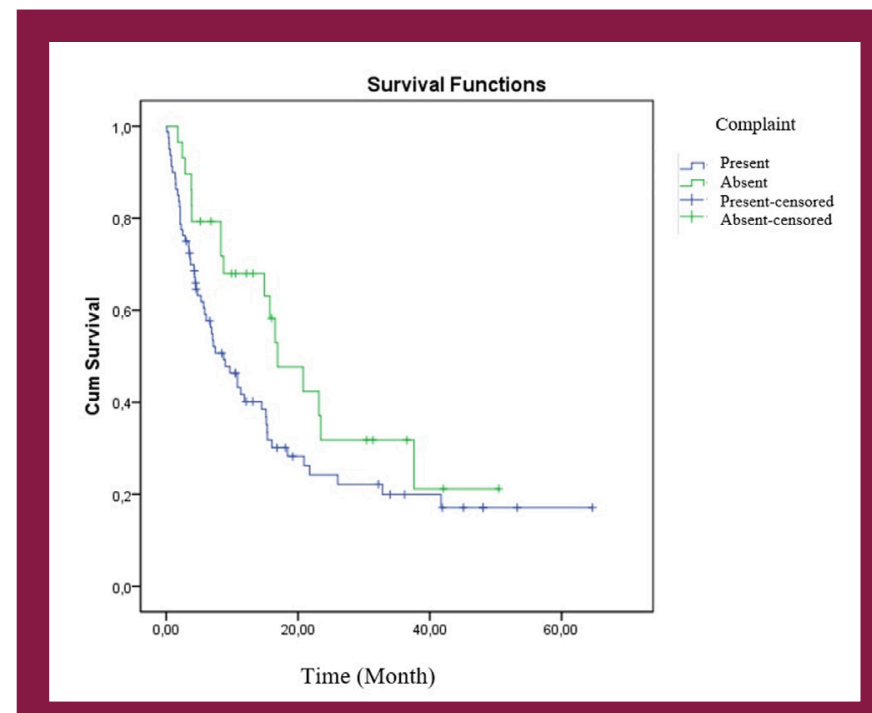

Figure 4. Survival curve of incidental and non-incidental PE patients

PE cases; PE mostly occurred within the first 6 months of cancer diagnosis; peripheral blood leukocyte and CRP values were higher; $\mathrm{Hb}$, hematocrit, protein and albumin values were lower and this group consisted of patients who did not receive chemotherapy. PE was found to be 2.3 percent in this study.

Anemia, leukocytosis, increased CRP, hypoalbuminemia and hypoproteinemia were found to be risk factors for PE in lung cancer in this study.

In the study of Sorenson et al. (20), in cancer cases with VTE, the risk of death in a year was found to be three times higher than in cases without VTE. A cohort analysis comparing the survival of cancer cases with and without
VTE showed that cases with VTE had a higher mortality rate (21). In another study, in which Ma and Wen (22) compared 30 cases with PE and 60 cases without PE, survival was shorter in the PE group.

Another research showed that PE was a weak prognostic factor in lung cancer cases, with cancer cases who had VTE leading to a lower life expectancy compared to those who did not (20). In our study, the mean survival time in the PE group was found to be 16 months shorter than in the nonPE group.

Anemia and leukocytosis in lung cancer patients have been studied as risk factors that may lead to the development of PE $(10,22,23,24)$. In this study, it was found that when the hemoglobin was less than $13.6 \mathrm{mg} / \mathrm{dL}$, the risk of PE increased by 5.1-fold and the leukocyte was more than $>10 \times 10 \mu / L$, the risk of PE increased by 2.8 -fold.

VTE, which involves DVT and PE, is thought to affect anywhere in $4 \%$ - $28 \%$ of cancer patients, depending on the type and stage of the tumor. Lung cancer is the sixth most common cause of PE, according to estimations (25). Despite this, there is little knowledge about the association between PE and lung cancer $(8,11,26,27)$. In our study, the incidence of PE was found to be $2.3 \%$, which is a lower rate in the incidence compared to the literature. One reason for the low incidence was because we considered it as the incidence of PE while they evaluated the incidence as VTE in the other studies. And the second one, there were probably many patients with asymptomatic VTE that were not detected and not all lung cancer patients remaining were screened for VTE.

Khorana et al. (28) found being a woman and over 65 years of age as risk factors for VTE, while Mehic et al. (29) found that the rate of VTE was three times more in men than in women. In their studies by Chew et al. (30), they did not show any difference between the two genders in terms of VTE. In our study, no significant difference was observed between the two groups in terms of age and sex.

PE appears to be associated with lung cancer not only by stage but also by histological type. Adenocarcinoma is thought to be the most thrombogenic tumor, making the cases more vulnerable to VTE $(7,8)$. Blom et al. (7) found that the risk of VTE was 20 times greater in non-small cell lung cancer cases than the majority, and that there was an elevated risk of VTE in adenocarcinoma cases compared to cases with squamous cell cancer. In another study, 8,014 cases with lung cancer were evaluated, and adenocarcinoma was found to be the most common histological type associated with PE (13). In our study, the rate of adenocarcinoma was higher in the PE group.

As in many studies, in a retrospective research, it was stated that VTE was detected more frequently in patients 
receiving chemotherapy for lung cancer than those who did not (31). However, in our research, the rate of receiving chemotherapy was significantly lower in the patients in the PE group. The reason for this is that chemotherapy was not applied due to the poor performance in our study.

In a large cohort research conducted by Blom et al. (32) in 2006, it was reported that the riskiest period for VTE was the onset period immediately after the diagnosis, and the risk later changed according to the presence of metastasis. In the study of Lee et al. (8) it is stated that PE can occur in a wide range from 3-4 months to 10 years after the diagnosis of lung cancer. There are also studies reporting that the incidence of VTE occurring in the first 6 months after lung cancer diagnosis is approximately 4 times higher than that occurring later $(7,33)$. PE developed in more than half of our patients (54.9\%) within the first 6 months in accordance with the literature.

Due to the advances in multi-detector CT technique and its increasing use in routine staging and monitoring of cancer patients, the frequency of detection of incidental PE has increased (34). In our study, where 4,842 lung cancer patients were scanned for 5 years, 29 out of 109 cases were detected incidentally. In a review of lung cancer cases conducted by Shinagare et al. (15) no substantial difference in survival was found between the two groups. In another retrospective research conducted in 2014, patients with asymptomatic PE were reported to have a better prognosis than the other group (31). In this report, when the mean survival time of the cases was evaluated, it was seen that there was a statistically significantly better life span in the incidental group compared to the other group. It was thought that this situation was as a result of the timely initiation of anticoagulant therapy in cases with incidental PE.

\section{Study Limitations}

This study has some limitations. Firstly, it was a retrospective research and it did not include all the cases diagnosed with lung cancer that had a VTE event. The clinical information of some patients was not available and some patients were followed up in another hospital after lung cancer diagnosis.

\section{Conclusion}

Accompanying $P E$ in lung cancer shortens the survival. Because the PE occurred more in patients with adenocarcinoma histology, leukocytosis, elevated CRP, anemia, and nutritional disorders, PE should be considered in these patients.

\section{Ethics}

Ethics Committee Approval: The study was designed retrospectively and approval was obtained from the Local Ethics Committee of the University of Health Sciences Turkey, Dr. Suat Seren Chest Diseases and Surgery Training and Research Hospital (no: 49109414-806.02.02).

Informed Consent: The study was designed retrospectively.

Peer-review: Externally and internally peer-reviewed.

\section{Authorship Contributions}

Surgical and Medical Practices: A.A., P.Ç., N.K., S.D., D.T., Concept: A.A., P.Ç., N.K., G.P., G.K., S.D., D.T., Design: A.A., P.Ç., G.P., G.K., D.T., Data Collection or Processing: A.A., N.K., S.D., Analysis or Interpretation: A.A., P.Ç., N.K., G.P., G.K., S.D., D.T., Literature Search: A.A., G.P., G.K., D.T., Writing: A.A., P.Ç., G.P., G.K., D.T.

Conflict of Interest: No conflict of interest was declared by the authors.

Financial Disclosure: The authors declared that this study received no financial support.

\section{REFERENCES}

1. Heit JA, O’Fallon WM, Petterson TM, Lohse CM, Silverstein MD, Mohr DN, et al. Relative impact of risk factors for deep vein thrombosis and pulmonary embolism: a population based study. Arch Intern Med. 2002;162:12451248. [CrossRef]

2. Falanga A, Marchetti M,Vignoli A. Coagulation and cancer: Biological and clinical aspects. J Thromb Haemost. 2013;11:223-233. [CrossRef]

3. Khorana AA, Francis CW, Culakova E, Lyman GH. Risk factors for chemotherapy associated venous thromboembolism in a prospective observational study. Cancer. 2005;104:2822-2829. [CrossRef]

4. Abdol RNB, Jones G, Bhandari M, Berndt MC, Metharom P. Cancerassociated thrombosis: an overview of mechanisms, risk factors, and treatment. Cancers (Basel). 2018;10:380. [CrossRef]

5. Astruc N, lanotto JC, Metges JP, Lacut K, Delluc A. External validation of the modified Ottawa score for risk stratification of recurrent cancerassociated thrombosis. Eur J Intern Med. 2016;36:e11-e12. [CrossRef]

6. Ay C,Unal UK. Epidemiology and risk factors for venous thromboembolism in lung cancer. Curr Opin Oncol. 2016;28:145-149. [CrossRef]

7. Blom JW, Osanto S, Rosendaal FR. The risk of a venous thrombotic event in lung cancer patients: higher risk for adenocarcinoma than squamous cell carcinoma.J Thromb Haemost. 2004;2:1760-1765. [CrossRef]

8. Lee JW, Cha SI, Jung CY, Choi WI, Jeon KN, Yoo SS, et al. Clinical course of pulmonary embolism in lung cancer patients. Respiration. 2009;78:4248. [CrossRef]

9. Xu X, Yang H, Qiao L, Tan Z, Jin J, Jin Y, et al. Clinical characteristic and outcomes of lung cancer patients with venous thromboembolism. Zhonghua Yi Xue Za Zhi. 2014;94:2045-2049. [CrossRef]

10. Sun W, Wang H, Wen Z, Ma N, Xiao Y, Ma L, et al. Clinical characteristics of lung cancer complicated with pulmonary embolism. Zhonghua Jie He Hu Xi Za Zhi. 2016;39:198-202.

11. Chuang YM, Yu CJ. Clinical characteristics and outcomes of lung cancer with pulmonary embolism. Oncology. 2009;77:100-106. [CrossRef]

12. Nichols L, Saunders R, Knollmann FD. Causes of death of patients with lung cancer. Arch Pathol Lab Med. 2012;136:1552-1557. [CrossRef] 
13. Sun JM, Kim TS, Lee J, Park YH, Ahn JS, Kim H, et al. Unsuspected pulmonary emboli in lung cancer patients: the impact on survival and the significance of anticoagulation therapy. Lung Cancer. 2010;69:330336. [CrossRef]

14. Silverstein MD, Heit JA, Mohr DN, Petterson TM, O’Fallon WM, Melton ப, et al. Trends in the incidence of deep vein thrombosis and pulmonary embolism: a 25 year population based study. Arch Intern Med 1998;158:585-593. [CrossRef]

15. Shinagare AB, Okajima Y, Oxnard GR, Dipiro PJ, Johnson BE, Hatabu H, et al. Unsuspected pulmonary embolism in lung cancer patients: comparison of clinical characteristics and outcome with suspected pulmonary embolism. Lung Cancer. 2012;78:161-166. [CrossRef]

16. Tiseo M, Bersanelli M, Barili MP, Bartolotti M, De Luca G, Gelsomino F, et al. Asymptomatic pulmonary embolism in lung cancer: Prevalence and analysis of clinical and radiological characteristics in 141 outpatients. Tumori. 2012;98:594-600. [CrossRef]

17. Goldstraw P, Chansky K, Crowley J, Rami Porta R, Asamura H, Eberhardt WEE, et al. The IASLC lung cancer staging project: Proposals for revision of the TNM stage groupings in the forthcoming (eighth) edition of the TNM Classification for lung cancer. J Thorac Oncol. 2016;11:39-51. [CrossRef]

18. Gladish GW, Choe DH, Marom EM, Sabloff BS, Broemeling LD, Munden RF. Incidental pulmonary emboli in oncology patients: prevalence, CT evaluation, and natural history. Radiology. 2006;240:246-255. [CrossRef]

19. The PIOPED Investigators. Value of the ventilation/ perfusion scan in acute pulmonary embolism. Results of the prospective investigation of pulmonary embolism diagnosis (PIOPED). JAMA. 1990;263:2753-2759. [CrossRef]

20. Sorensen HT, Mellemkjær L, Olsen JH, Baron JA. Prognosis of Cancers Associated with Venous Thromboembolism.N EnglJ Med.2000;343:18461850. [CrossRef]

21. Chew HK, Wun T, Harvey D, Zhou H, White RH. Incidence of venous thromboembolism and its effect on survival among patients with common cancers. Arch Intern Med. 2006;166:458-464. [CrossRef]

22. Ma L, Wen Z. Risk factors and prognosis of pulmonary embolism in patients with lung cancer. Medicine (Baltimore) 2017;96:e6638. doi: 10.1097/MD.0000000000006638. [CrossRef]

23. Li N,Wang Y.Clinical features in 23 lung cancer patients complicated with pulmonary thromboembolism. Zhongguo Fei Ai Za Zhi. 2014;17:254-259. [CrossRef]
24. Zhang Y, Yang Y, Chen W, Guo L, Liang L, Zhai Z, et al. Prevalence and associations of VTE in patients with newly diagnosed lung cancer. Chest. 2014;146:650-658. [CrossRef]

25. Shinagare AB, Guo M, Hatabu H, Krajewski KM, Andriole K, Van Den Abbeele AD, et al. Incidence of pulmonary embolism in oncologic outpatients at a tertiary cancer center. Cancer. 2011;117:3860-3866. [CrossRef]

26. Sakuragi T, Sakao Y, Furukawa K, Rikitake K, Ohtsubo S, Okazaki Y, et al. Successful management of acute pulmonary embolism after surgery for lung cancer. Eur J Cardio thoracic Surg. 2003;24:580-587. [CrossRef]

27. Shao L, Wang ZH, Zuo JY. Clinical analysis of 23 lung cancer patients accompanied by pulmonary embolism. Ai Zheng. 2009;28:416-419. [CrossRef]

28. Khorana AA, Francis CW, Culakova E, Kuderer NM, Lyman GH. Frequency, risk factors, and trends for venous thromboembolism among hospitalized cancer patients. Cancer. 2007;110:2339-2346. [CrossRef]

29. Mehic B, Zutic H, Mehic A. Profile of venous thromboembolism at the patients with non small cell lung carcinoma. HealthMED. 2009;3:3-7. [CrossRef]

30. Chew HK, Davies AM, Wun T, Harvey D, Zhou H, White RH. The incidence of venous thromboembolism among patients with primary lung cancer.J Thromb Haemost. 2008;6:601-608. [CrossRef]

31. Alexander M, Kirsa S, Wolfe R, MacManus M, Ball D, Solomon B, et al. Thromboembolism in lung cancer $\mathrm{An}$ area of urgent unmet need. Lung Cancer. 2014;84:275-280. [CrossRef]

32. Blom JW, Vanderschoot JPM, Oostindiër MJ, Osanto S, van der Meer FJM, Rosendaal FR. Incidence of venous thrombosis in a large cohort of 66,329 cancer patients: results of a record linkage study. J Thromb Haemost. 2006;4:529-535. [CrossRef]

33. Blom JW, Doggen CJM, Osanto S, Rosendaal FR. Malignancies, prothrombotic mutations, and the risk of venous thrombosis. J Am Med Assoc. 2005;293:715-722. [CrossRef]

34. Gosselin M V, Rubin GD, Leung AN, Huang J, Rizk NW. Unsuspected pulmonary embolism: prospective detection on routine helical CT scans. Radiology. 1998;208:209-215. [CrossRef] 